\author{
PIOTR RODZIEWICZ \\ ORCID: 0000-0002-1666-4202 \\ Uniwersytet Wrocławski \\ Instytut Prawa Cywilnego \\ Zakład Prawa Cywilnego i Prawa Międzynarodowego Prywatnego
}

\title{
WARTOŚCI PREFEROWANE PRZEZ RACJONALNEGO PRAWODAWCE W PRAWIE PRYWATNYM MIĘDZYNARODOWYM
}

\begin{abstract}
Abstrakt: Normy kolizyjne prawa prywatnego międzynarodowego cechuje odmienna budowa od norm prawa merytorycznego (materialnego), co uwarunkowane jest celem, któremu służą. W literaturze wskazuje się, że normy kolizyjne prawa prywatnego międzynarodowego mają charakter norm technicznych, w związku z tym pojawia się pytanie, są one nośnikiem wartości, analogicznie jak normy prawa materialnego. Odpowiedź twierdząca wymaga dalszego rozstrzygnięcia, a mianowicie urzeczywistnieniu jakich wartości normy te służą, a także które wartości powinny być szczególnie preferowane przez racjonalnego prawodawcę. Celem niniejszego opracowania jest udzielenie odpowiedzi na pytanie, czy i jakie wartości, a także w jaki sposób urzeczywistniają normy kolizyjne prawa prywatnego międzynarodowego tworzone przez racjonalnego prawodawcę.
\end{abstract}

Słowa kluczowe: część ogólna prawa prywatnego międzynarodowego, wartości w prawie prywatnym międzynarodowym, autonomia woli stron w prawie prywatnym międzynarodowym, najściślejszy związek w prawie prywatnym międzynarodowym, wskazanie prawa właściwego

\section{ZAGADNIENIA WSTĘPNE}

Założenie racjonalności prawodawcy sprowadza się do przyjęcia, że ma on aktualną wiedzę oraz doświadczenie odnoszące się do sfery stosunków społecznych będących przedmiotem podejmowanych przez niego działań legislacyjnych ${ }^{1}$. Jednocześnie racjonalny prawodawca podejmuje działania prawotwórcze w zgodzie z hierarchicznym systemem wartości, którego elementy składowe mogą zostać zdekodowane z tekstów aktów normatywnych ${ }^{2}$. Mając to na uwadze, należy

${ }^{1}$ Zob. M. Krotoszyński, Legislative history, ratio legis, and the concept of rational legislator, [w:] Ratio Legis. Philosophical and Theoretical Perspectives, red. V. Klappstein, M. Dybowski, Heidelberg 2018, s. 66.

2 Zob. ibidem. 
rozważyć, czy normy prawa prywatnego międzynarodowego w ścisłym ujęciu ${ }^{3}$, cechujące się odmienną strukturą i budową niż normy prawa materialnego (merytorycznego $)^{4}$, są nośnikiem wartości. W wypadku odpowiedzi afirmatywnej zasadne jest udzielenie odpowiedzi na pytanie, jakie wartości są szczególnie preferowane przez racjonalnego prawodawcę $\mathrm{w}$ prawie prywatnym międzynarodowym. Oczywiście odmienność budowy norm prawa prywatnego międzynarodowego względem norm prawa materialnego wynika z celów, jakie normy te realizują. Problematyczne jest jednak ustalenie, w odniesieniu do wskazanych norm, czy w ogóle można uznać, że służą one urzeczywistnieniu określonych wartości, skoro według niektórych głosów mają one jedynie charakter techniczny ${ }^{5}$. W literaturze w tym zakresie można spotkać odmienne poglądy, zarówno negujące możliwość pełnienia funkcji nośnika wartości przez normy kolizyjne prawa prywatnego międzynarodowego ${ }^{6}$, jak i wskazujące, że są one nośnikiem wartości, jednak odmiennych niż normy prawa materialnego ${ }^{7}$. Jednocześnie zauważalna jest tendencja sprowadzająca się do zmiany podejścia do mechanizmu służącego wskazaniu prawa właściwego, a w konsekwencji charakteru wartości, których urzeczywistnieniu powinien służyć mechanizm kolizyjnoprawny ${ }^{8}$. Jest to szczególnie widoczne, gdy dokona się zestawienia tradycyjnych poglądów wyrażanych w zakresie tego, jakie wartości powinny być preferowane przez normy kolizyjne prawa prywatnego międzynarodowego ${ }^{9}$, z założeniami metody analizy funkcjonalnej ${ }^{10}$, w ramach

${ }^{3}$ Zob. więcej M. Pazdan, [w:] System Prawa Prywatnego, t. 20A. Prawo prywatne międzynarodowe, red. M. Pazdan, Warszawa 2014, s. 11.

4 Por. H. Trammer, Z rozważań nad struktura normy kolizyjnej prawa prywatnego międzynarodowego, S.C. 12-14, 1969, s. 402 n.

5 Por. R. Michaels, Private international law and the question of universal values, [w:] Private International Law Contemporary Challenges and Continuing Relevance, red. F. Ferrari, D.P.F. Arroyo, Cheltenham 2019, s. 165 n.

${ }^{6}$ Zob. F.B. Vischer, General course on private international law (volume 232), [w:] Collected Courses of the Hague Academy of International Law, Dordrecht-Boston-London 1992, s. 93.

7 Por. O. Remien, Germany: Proof of and information about foreign law - duty to investigate, expert opinions and a proposal for Europe, [w:] Treatment of Foreign Law - Dynamics towards Convergence?, red. Y. Nishitani, Cham 2017, s. 209.

8 Por. R. Michaels, op. cit., s. 162; K. Sachse, Der Verbrauchervertrag im Internationalen Privat- und Prozessrecht, Tübingen 2006, s. 12; J. Poczobut, [w:] Prawo prywatne międzynarodowe. Komentarz, red. J. Poczobut, Warszawa 2017, s. 43.

9 Zob. A. Shapira, Tort choice of law in Israel: Putting order in a methodological chaos, [w:] Private Law in the International Arena: From National Conflict Rules Towards Harmonization and Unification - Liber Amicorum Kurt Siehr, red. J. Basedow et al., Haga 2000, s. 696; T. De Boer, Teaching private international law and comprative law, [w:] Contemporary International Law Issues: Opportunities at a Time of Momentous Change: Proceedings of the Second Joint Conference Held in The Hague, The Netherlands, July 22-24, 1993, Dordrecht-Boston-London 1994, s. 275.

10 Zob. J. Boroń, M. Dąbroś, Z. Dziadek, Metoda analizy funkcjonalnej - równoprawna metoda kolizyjna?, [w:] Problemy prawa prywatnego międzynarodowego, t. 15, red. M. Pazdan, Katowice 2014, s. 72. 
której akcent zdecydowanie został przesunięty na płaszczyznę wartości, które są realizowane przez normy prawa merytorycznego ${ }^{11}$.

Mając powyższe na uwadze, niniejsze opracowanie zmierza do sformułowania odpowiedzi na pytania, czy i jakie wartości, a także w jaki sposób urzeczywistniają normy kolizyjne prawa prywatnego międzynarodowego tworzone przez racjonalnego prawodawcę.

\section{PRAWO PRYWATNE MIĘDZYNARODOWE JAKO NOŚNIK WARTOŚCI}

Normy prawne składające się na prawo prywatne międzynarodowe nie mają charakteru jednorodzajowego ${ }^{12}$. Co więcej, nie ma jednolitości poglądów odnoszących się do zakresu prawa prywatnego międzynarodowego ${ }^{13}$. Nie wchodząc jednak w szczegółowe rozważania, analizie poddane zostaną normy kolizyjne prawa prywatnego międzynarodowego, a więc normy zawarte w przepisach prawa prywatnego międzynarodowego w ujęciu wąskim. Mniej bowiem problematyczna wydaje się kwestia wartości urzeczywistnianych przez normy prawa prywatnego międzynarodowego w ujęciu szerokim, albowiem zarówno normy prawa jednolitego ${ }^{14}$, jak i normy prawa obcych ${ }^{15}$ stanowią normy merytoryczne (prawa materialnego), które wyznaczają bezpośrednio zachowania ich adresatów. Natomiast rola norm kolizyjnych prawa prywatnego międzynarodowego sprowadza się do rozgraniczenia sfer działania systemów prawnych różnych państw i wskazania prawa właściwego dla sytuacji życiowych z zakresu prawa prywatnego. Jak wskazuje się w doktrynie, ze względu na pełnione funkcje normy kolizyjne mają techniczny charakter ${ }^{16}$, czy też są zespołem „norm o normach" ${ }^{17}$. Cechą charakterystyczną norm kolizyjnych jest to, że są one normami, od których zależy zastosowanie innych norm - prawa merytorycznego. Niezależnie od tego normy prywatnego prawa materialnego i normy prawa prywatnego międzynarodowego mają wspólną cechę, która polega na tym, że obie grupy norm dotyczą stosunków prawnych o charakterze prywatnoprawnym ${ }^{18}$. Elementem odróżniającym jest natomiast to, że normy merytoryczne wprost wskazują konsekwencje prawne zaistnienia określonych stanów faktycznych ujętych w sposób abstrakcyjny w ich hipotezach, wyznaczając tym samym treść stosunków prawnych, podczas gdy normy

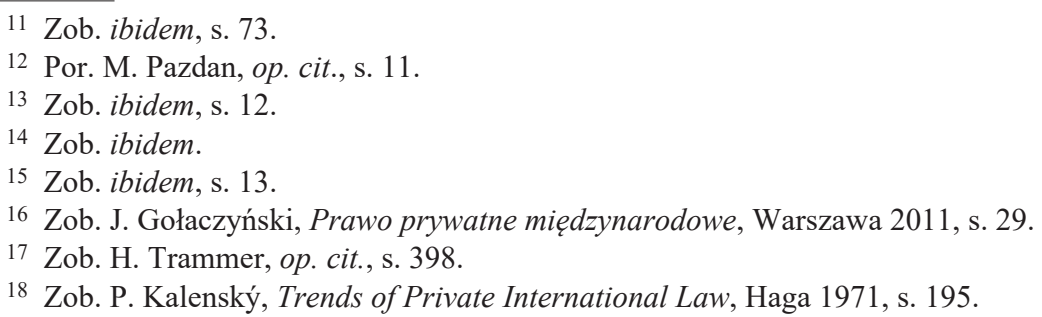


kolizyjne wskazują jedynie, który z systemów norm merytorycznych powinien zostać zastosowany do określonej sytuacji życiowej. Normy kolizyjne oddziałują na określoną rzeczywistość społeczną w sposób pośredni ${ }^{19}$.

Ze względu na techniczny charakter norm kolizyjnych w literaturze wyrażane były wątpliwości, czy i jakim wartościom służą normy kolizyjne prawa prywatnego międzynarodowego. Techniczny charakter norm kolizyjnych uzasadnia stwierdzenie, że normy kolizyjne prawa prywatnego międzynarodowego nie są nośnikiem tych samych wartości co normy merytoryczne ${ }^{20}$. Nie oznacza to jednak, że normy kolizyjne nie są w ogóle nośnikiem wartości, wręcz przeciwnie — stoją one na straży wartości, ale innych aniżeli normy prawa materialnego ${ }^{21}$.

Zgodnie z poglądem wyrażonym przez G. Kegela ${ }^{22}$ możliwe jest wyróżnienie sprawiedliwości materialnoprawnej, na straży której stoją normy prawa materialnego, oraz sprawiedliwości na płaszczyźnie prawa prywatnego międzynarodowego, której osiągnięcie jest celem norm kolizyjnych ${ }^{23}$. Celem sprawiedliwości na drugiej ze wskazanych płaszczyzn jest między innymi to, aby określona sytuacja życiowa była regulowana przez prawo państwa najbliżej związanego z daną sytuacja życiową ${ }^{24}$, zastosowanie norm kolizyjnych prowadziło do jednolitych skutków na płaszczyźnie wskazania prawa właściwego, prawo państwa forum i prawo obce były traktowane w równy sposób, a wskazanie prawa właściwego było przewidywalne ${ }^{25}$. Mając to na uwadze, należy uznać, że techniczny charakter norm kolizyjnych prawa prywatnego międzynarodowego wcale nie jest cechą przesądzającą o tym, czy normy kolizyjne mogą być nośnikiem wartości. Techniczny charakter norm kolizyjnych wynika z celu, jakiemu one służą, lecz nie powoduje, że normy kolizyjne przestają być nośnikiem wartości. Jednakże wskazany cel determinuje katalog wartości realizowanych przez normy kolizyjne, natomiast racjonalny prawodawca, podejmując decyzje prawodawcze, dokonuje preferencji określonych wartości, urzeczywistniając poszczególne z nich w większym lub mniejszym stopniu.

19 K. Lipstein, Principles of The Conflict of Laws, National and International, Haga 1981, s. 2.

20 Zob. P. Rodziewicz, Stwierdzenie treści oraz zastosowanie prawa obcego w sadowym postepowaniu cywilnym, Warszawa 2015, s. $18 \mathrm{n}$.

21 Por. R. Michaels, op. cit., s. 165 n.

22 Zob. G. Kegel, The crisis of conflicts of laws (volume 112), [w:] Collected Courses of the Hague Academy of International Law, Sijthoff 1964, s. 132.

23 Por. S.C. Symeonides, Codyfing Choice of Law Around the World. An International Comparative Analysis, Oxford 2014, s. 246 n.; T. De Boer, Facultative choice of law: The procedural status of choice-of-law rules and foreign law, [w:] Le Recueil des cours, t. 257 (1996), Haga 1997, s. $291 \mathrm{n}$.

24 M. Bogdan, Private International Law as Component of the Law of the Forum, General Course, Haga 2012, s. 91 n.

25 Por. R. Michaels, op. cit., s. 159. 


\section{TRADYCYJNE WARTOŚCI REALIZOWANE PRZEZ NORMY KOLIZYJNE PRAWA PRYWATNEGO MIĘDZYNARODOWEGO}

Przechodząc do prezentacji wartości realizowanych przez normy kolizyjne prawa prywatnego międzynarodowego, należy poczynić zastrzeżenie, że ze względu na ramy niniejszego opracowania wyczerpujące omówienie wszystkich poglądów w tym zakresie nie jest możliwe. W związku z tym rozważania zostaną ograniczone jedynie do wartości powszechnie akceptowanych w doktrynie ${ }^{26}$, które mają najistotniejsze znaczenie z punktu widzenia aktywności podejmowanej przez racjonalnego prawodawcę.

Pomiędzy wartościami realizowanymi przez normy kolizyjne prawa prywatnego międzynarodowego istnieje wzajemne oddziaływanie przejawiające się w tym, że preferowanie jednej wartości może prowadzić do ograniczenia stopnia urzeczywistnienia innej. Mając to na uwadze, warto zauważyć, że wartości te nie pozostają w relacji komplementarnej, ale mają charakter konkurencyjny. Zasadniczo wszystkie z omawianych dalej wartości są realizowane przez normy kolizyjne prawa prywatnego międzynarodowego, niemniej jednak w zależności od konkretnej decyzji prawodawczej stopień urzeczywistnienia poszczególnych wartości może być zmienny.

Tradycyjnie przyjmuje się, że wartością realizowaną przez normy kolizyjne jest pewność i przewidywalność wskazania prawa właściwego dla określonej sytuacji życiowej27. Wartość ta jest realizowana przez normy kolizyjne oparte na łącznikach obiektywnych. Łagodzeniu rygorów związanych ze stosowaniem pojedynczych łączników obiektywnych może służyć użycie w strukturze normy kolizyjnej łączników kaskadowych ${ }^{28}$. W opozycji do przewidywalności wskazania prawa właściwego znajduje się elastyczność w zakresie wskazania prawa, która jest realizowana zarówno przez wprowadzenie przez prawodawcę klauzul korekcyjnych (corrective clause $^{29}$ ), jak i dopuszczenie wyboru prawa właściwego. Na etapie tworzenia norm kolizyjnych prawodawca in abstracto determinuje w ramach łącznika normy kolizyjnej okoliczność lub zespół okoliczności, które w jego ocenie powinny decydować o powiązaniu określonej sytuacji życiowej z prawem dla niej właściwym. Prawodawca zazwyczaj stosuje takie łączniki, które in abstracto pozwalają na powiązanie sytuacji życiowej z prawem pozostającym

26 Por. L. Brilmayer, The role of substantive and choice of law policies in the formation and application of choice of law rules (volume 252), [w:] Collected Courses of the Hague Academy of International Law, Dordrecht-Boston-London 1995, s. 60 n.; F.B. Vischer, op. cit., s. 125 n.; K. Roosevelt, Certainty vs. flexibility in the conflict of laws, [w:] Private International Law Contemporary Challenges..., s. $2 \mathrm{n}$.

27 Por. K. Roosevelt, op. cit., s. 8.

28 Por. T. Pajor, Nowe tendencje w części ogólnej prawa prywatnego międzynarodowego państw europejskich, PPHZ 1995, nr 18, s. 63, 65.

29 Zob. więcej F. Ragno, Certainity versus flexibility in the EU choice of law system, [w:] Private International Law Contemporary Challenges..., s. 53; F.B. Vischer, op. cit., s. $108 \mathrm{n}$. 
z nią w najściślejszym związku ${ }^{30}$. Jednakże za przyjęciem łącznika w określonym kształcie mogą przemawiać również względy innej natury. Jako przykład można wskazać racje przemawiające za posłużeniem się przez prawodawcę łącznikiem obywatelstwa. Jednym z argumentów uzasadniających odwołanie się do łącznika obywatelstwa i prawa ojczystego jest przywiązanie osoby fizycznej do jej państwa pochodzenia, którego najczęściej nie przekreśla nawet emigracja tej osoby ${ }^{31}$. Należy jednak zauważyć, że okoliczności zawarte w łączniku normy kolizyjnej, antycypowane przez prawodawcę in concerto mogą zawodzić i prowadzić do sytuacji, w której prawo właściwe nie będzie faktycznie najściślej związane z regulowaną sytuacją życiową. W takich sytuacjach uelastycznieniu wskazania prawa właściwego mają służyć klauzule korekcyjne ${ }^{32}$.

Instytucja wyboru prawa właściwego w prawie prywatnym międzynarodowym również służy uelastycznieniu wskazania prawa właściwego. Jednak zasadniczym jej celem jest urzeczywistnienie wartości w postaci swobody kształtowania sytuacji prawnej przez podmioty prawa prywatnego. Stanowi ona przejaw autonomii woli stron w prawie prywatnym międzynarodowym, będącej jednocześnie przejawem autonomii woli w szczerszym znaczeniu ${ }^{33}$, składającej się na wolność jednostki w kształtowaniu jej sytuacji prawnej. Prawodawca, konstruując normy kolizyjne zezwalające na możliwość dokonania wyboru, zazwyczaj staje przed dylematem dotyczącym granic autonomii jednostki w tym zakresie. Autonomia może zostać przyznana podmiotom prawa w sposób nieograniczony (na przykład art. 3 Rzym I34) lub ograniczony (na przykład art. 14 Rzym II ${ }^{35}$, art. 22 rozporządzenia spadkowego ${ }^{36}$, art. 52 ust. 1 p.p.m. ${ }^{37}$ ).

Inną powszechnie akceptowaną wartością jest jednolitość rozstrzygnięć (wskazania prawa właściwego) w płaszczyźnie międzynarodowej ${ }^{38}$, która może

30 Zob. M. Czepelak, Międzynarodowe prawo zobowiązań Unii Europejskiej, Warszawa 2012, s. 66 .

31 Zob. M. Pilich, Zasada obywatelstwa w prawie prywatnym międzynarodowym. Zagadnienia podstawowe, Warszawa 2015, s. 274.

32 Por. A.J. Belohlávek, Rome Convention - Rome I Regulation. Commentary, Juris 2010, s. 808.

33 Por. P. Machnikowski, Swoboda umów wedlug art. $353^{1}$ KC. Konstrukcja prawna, Warszawa 2005, s. 19.

${ }^{34}$ Rozporządzenie Parlamentu Europejskiego i Rady (WE) nr 593/2008 z dnia 17 czerwca 2008 roku w sprawie prawa właściwego dla zobowiązań umownych (dalej: Rzym I).

35 Rozporządzenie (WE) nr 864/2007 Parlamentu Europejskiego i Rady z dnia 11 lipca 2007 roku dotyczące prawa właściwego dla zobowiązań pozaumownych (dalej: Rzym II).

36 Rozporządzenie Parlamentu Europejskiego i Rady (UE) nr 650/2012 z dnia 4 lipca 2012 roku w sprawie jurysdykcji, prawa właściwego, uznawania i wykonywania orzeczeń, przyjmowania i wykonywania dokumentów urzędowych dotyczących dziedziczenia oraz w sprawie ustanowienia europejskiego poświadczenia spadkowego (dalej: rozporządzenie spadkowe).

37 Ustawa z dnia 4 lutego 2011 roku — Prawo prywatne międzynarodowe, Dz.U. z 2015 r. poz. 1792 (dalej: p.p.m.).

38 Por. K. Roosevelt, op. cit., s. 8; M. Pilich, op. cit., s. 269. 
zostać urzeczywistniona przez zastosowanie łącznika powszechnie akceptowanego jako kryterium wskazania prawa właściwego dla określonej sytuacji życiowej. Istnieją grupy sytuacji życiowych, które w przeważającej mierze są przedmiotem regulacji krajowych aktów normatywnych z zakresu prawa prywatnego międzynarodowego. Jednocześnie prawodawcy wskazują prawo właściwe dla nich za pomocą powszechnie akceptowanych łączników, co pomimo braku formalnego ujednolicenia regulacji w płaszczyźnie międzynarodowej czy regionalnej prowadzi do kolizyjnoprawnej jednolitości rozstrzygnięć. Najlepszym przykładem opisanej sytuacji jest wskazanie prawa właściwego dla statutu rzeczowego. Powszechnie stosowanym łącznikiem w tym zakresie jest łącznik miejsca położenia przedmiotu praw (lex rei sitae), co powoduje, że pomimo braku ujednoliconej regulacji kolizyjnoprawnej w płaszczyźnie unijnej oraz międzynarodowej, wskazanie prawa właściwego dla własności i innych praw rzeczowych następuje w jednolity sposób ${ }^{39}$.

Wartością, jaką według niektórych autorów mogą realizować normy kolizyjne prawa prywatnego międzynarodowego, jest również responsywność (responsivity ${ }^{40}$. Responsywność $\mathrm{w}$ prawie prywatnym międzynarodowym powinna być rozumiana jako otwartość na mnogość perspektyw wynikających z odmienności praw poszczególnych państw ${ }^{41}$. Responsywaność oznacza, że nawet jeśli określone sytuacje życiowe nie są regulowane w danym państwie, z perspektywy którego ma nastąpić ustalenie prawa właściwego, wcale nie oznacza to, że sytuacje te powinny pozostać bez odpowiedzi. Responsywność przy tym nie wiąże się z koniecznością przyjęcia obcych rozwiązań i legalizacji stanów rzeczy niedopuszczonych według lex fori. Oznacza ona konieczność dostrzeżenia potrzeby uznania określonych sytuacji życiowych i jednocześnie wypowiedzenia się co do nich. Oczywiście nie sprawia to, że mają one podlegać automatycznej akceptacji. Odwołując się do przykładu pochodzącego z doktryny, należy zauważyć, że jeżeli sąd w państwie, w którym związki osób tej samej płci nie są uznawane, stanie przed potrzebą ustalenia prawa właściwego dla skutków majątkowych takiego związku, powinien dostrzec i odpowiednio zakwalifikować, a także znaleźć właściwe

39 Jako przykład można wskazać następujące akty prawa krajowego, które oparte są na łączniku prawa państwa położenia przedmiotu praw (rzeczy) — lex rei sitae: art. 41 ust. 1 p.p.m.; art. 43 (1) Einführungsgesetz zum Bürgerlichen Gesetzbuche (przepisów wprowadzających niemieckiego kodeksu cywilnego); § 18 (2) Rahvusvahelise eraõiguse seadus (estońskiej ustawy prawo prywatne międzynarodowe); § 39 (1) magyarország hivatalos lapja (węgierskiej ustawy prawo prywatne międzynarodowe).

40 R. Michaels, op. cit., s. 174.

${ }^{41}$ Ibidem, s. 175; por. także R. Michaels, Private international law as an ethic of responsivity (September 14, 2018). Forthcoming, diversity and integration in private international law (Veronica Ruiz Abou-Nigm \& Maria Blanca Noodt Taquela eds, Edinburgh University Press, 2019), „Duke Law School Public Law \& Legal Theory Series” 2018, nr 57, s. 8, https://ssrn.com/abstract=3251422 (dostęp: 15.05.2020). 
rozwiązanie ${ }^{42}$. Z brakiem realizacji powyższej wartości mielibyśmy do czynienia, gdyby organ stosujący prawo stwierdził, że nie dostrzega potrzeby rozstrzygnięcia o istnieniu takiej sytuacji życiowej (sytuacji takiej w ogóle nie dostrzeże). Odnosząc powyższe do płaszczyzny wartości preferowanych przez racjonalnego prawodawcę, należy przyjąć, że polski prawodawca preferuje wartość w postaci responsywności norm kolizyjnych, czemu dał wyraz w przepisie art. 67 p.p.m. Zawarta w nim została ogólna wskazówka służąca ustaleniu prawa właściwego, gdy określona sytuacja życiowa jest nieunormowana w obowiązujących przepisach oraz w sytuacji mieszczącej się prima facie w zakresie zastosowania określonej normy kolizyjnej wskazującej prawo właściwe, jednak wyłączonej poza jej zasięg ze względu na uszczegółowienie jej zakresu o wnioski płynące z bazy faktycznej łącznika ${ }^{43}$. W związku z tym należy zauważyć, że nieprzystąpienie Polski do wzmocnionej współpracy dotyczącej małżeńskich stosunków majątkowych i skutków majątkowych związków partnerskich ${ }^{44}$ wcale nie oznacza, że polski prawodawca nie urzeczywistnia wartości w postaci responsywności, albowiem prawo właściwe dla wskazanych sytuacji życiowych może zostać wskazane z uwzględnieniem art. 67 p.p.m.

Normy kolizyjne prawa prywatnego międzynarodowego służą urzeczywistnieniu wartości, których treść jest inna niż w wypadku norm prawa materialnego. Poszczególne wartości są urzeczywistniane przez normy kolizyjne z różnym natężeniem, w zależności od preferowanych stanów, jakie zamierza osiągnąć racjonalny prawodawca, dysponujący wiedzą i doświadczeniem w obszarze będącym przedmiotem decyzji prawodawczych.

\section{WPŁYW MULTICENTRYCZNOŚCI SYSTEMU ŹRÓDEŁ PRAWA PRYWATNEGO MIĘDZYNARODOWEGO NA WARTOŚCI PREFEROWANE PRZEZ RACJONALNEGO PRAWODAWCE}

Z perspektywy prawa prywatnego międzynarodowego szczególnie widoczne jest, że system prawny obowiązujący w Polsce nie jest układem monocentrycznym, ale ma wyraźną multicentryczną postać ${ }^{45}$. Prowadzi to do wielu implikacji, w głównej mierze na płaszczyźnie stosowania norm kolizyjnych prawa prywatne-

42 R. Michaels, Private..., s. 174.

43 M. Zachariasiewicz, Prawo prywatne międzynarodowe. Komentarz, red. M. Pazdan, Warszawa 2018, s. 546.

44 Zob. P. Mostowik, O uzasadnionych powodach nieprzystapienia Polski do rozporządzen UE $n$ r 2016/1103 i 2016/1104 dotyczących wewnętrznych i zewnętrznych relacji malżonków i rejestrowanych partnerów, [w:] Kolizyjne i procesowe aspekty prawa rodzinnego, red. J. Gołaczyński, W. Popiołek, Warszawa 2019, s. 107 n.

45 Por. E. Łętowska, Multicentryczność wspótczesnego systemu prawa i jej konsekwencje, „Państwo i Prawo” 2005, nr 4, s. 3. 
go międzynarodowego ${ }^{46}$, gdy zakresy poszczególnych statutów wydających się pozostawać w zbiegu, w ramach określonej sytuacji życiowej, są wskazywane przez normy kolizyjne pochodzące z różnych źródeł ${ }^{47}$. Multicetryczność systemu prawnego obowiązującego w Polsce dostrzegają również poszczególne centra decyzyjne, co ma wpływ na podejmowane przez nie działania prawodawcze. Najlepszym przykładem mogą być prace nad ustawą p.p.m., w trakcie których krajowy prawodawca antycypował istniejącą i przyszłą sytuację związaną z obowiązywaniem aktów normatywnych zawierających normy kolizyjne przyjęte w ramach Unii Europejskiej. Krajowy prawodawca nie objął zakresem regulacji sytuacji życiowych ujętych w aktach prawa unijnego, jednocześnie wprowadził wycinkową regulację odnoszącą się do sytuacji życiowych wyłączonych z zakresu zastosowania Rzym I (na przykład art. 28 ust. 2 p.p.m., art. 29 i 30 p.p.m.) i Rzym II (na przykład art. 16 ust. 2 p.p.m. w zakresie ochrony dóbr osobistych oraz art. 35 p.p.m. w zakresie odpowiedzialności za działania lub zaniechania przy wykonywaniu władzy publicznej) ${ }^{48}$. Niezależnie od tego warto zwrócić uwagę, że krajowy prawodawca zastosował analogiczną metodę regulacji prawa właściwego dla zobowiązań wynikających z jednostronnych czynności prawnych, jaka przyjęta została dla zobowiązań umownych w prawie unijnym. Dopuścił bowiem wybór prawa, posłużył się łącznikiem obiektywnym na wypadek braku wyboru, wprowadzając jednocześnie klauzulę korekcyjną, która stosunkowo rzadko jest stosowana w prawie krajowym.

Multicentryczność systemu źródeł prawa prywatnego międzynarodowego ma również istotne znaczenie z punktu widzenia ustalenia wartości preferowanych przez racjonalnego prawodawcę w prawie prywatnym międzynarodowym. Należy bowiem zauważyć, że istnienie różnych centrów decyzyjnych będących źródłami aktów prawodawczych w obszarze prawa prywatnego międzynarodowego może wpływać na niejednolitość w zakresie preferowanych wartości, co w konsekwencji doprowadzi do sytuacji, w której trudno będzie ustalić jednolity katalog i hierarchię wartości leżących u podstaw decyzji prawotwórczych w obszarze prawa prywatnego międzynarodowego. Oczywiście możliwa jest sytuacja jak w opisanym przypadku, w którym ustawodawca krajowy wzorował się na prawodawcy unijnym. Niemniej jednak nie przesądza to, że sposób regulacji, a w konsekwencji wartości preferowane przez poszczególne centra decyzyjne, jakie mają urzeczywistniać normy kolizyjne, będą zbieżne.

46 Por. A. Kalisz, Multicentryczność systemu prawa polskiego a działalność orzecznicza Europejskiego Trybunału Sprawiedliwości i Europejskiego Trybunału Praw Człowieka, „Ruch Prawniczy, Ekonomiczny i Socjologiczny" 2007, z. 4, s. 36 n.

47 Por. M. Pazdan, Koordynacja krajowego i europejskiego prawa prywatnego międzynarodowego, [w:] Wspótczesne wyzwania prawa prywatnego międzynarodowego, red. J. Poczobut, Warszawa 2013, s. 226.

48 Tak uzasadnienie rządowego projektu ustawy - Prawo prywatne międzynarodowe, druk 1277, s. 5, http://orka.sejm.gov.pl/proc6.nsf/opisy/1277.html. (dostęp: 15.05.2020) 
Odnosząc to do przykładu, prawodawca krajowy, tworząc akty prawa krajowego, w o wiele mniejszym stopniu odwołuje się do klauzuli korekcyjnej ściślejszego związku niż prawodawca unijny. Powoduje to, że krajowe normy kolizyjne cechuje przewidywalność wskazania prawa właściwego w wyższym stopniu niż normy kolizyjne zawarte w aktach prawa unijnego, które pozwalają organowi stosującemu prawo na większą elastyczność w procesie wyznaczania prawa właściwego ${ }^{49}$. W ustawie p.p.m. klauzula korekcyjna została zawarta jedynie w odniesieniu do norm kolizyjnych opartych na łącznikach obiektywnych i wskazujących prawo właściwe dla zobowiązań wynikających z jednostronnych czynności prawnych (o czym była mowa - art. 32 ust. 2 p.p.m.) oraz prawo właściwe dla praw rzeczowych na rzeczy w transporcie, tak zwanych res in transitu (art. 43 zd. 2 p.p.m.). Natomiast w zakresie wskazania prawa właściwego dla stosunków osobistych i majątkowych małżeńskich (art. 51 ust. 2 zd. 3 p.p.m.) oraz prawa właściwego dla przysposobienia wspólnego małżonków (art. 57 ust. 2 zd. 3 p.p.m.) kryterium ścisłego związku jest tylko jedną z reguł pomocniczych ${ }^{50}$, nie pełni tym samym funkcji klauzuli korekcyjnej. Odmienne podejście do klauzuli korekcyjnej prezentuje prawodawca unijny. Jest ona jednym z zasadniczych elementów mechanizmu kolizyjnoprawnego zawartego w Rzym I, Rzym II, a także rozporządzenia spadkowego. To sprawia, że preferencje poszczególnych centrów decyzyjnych $\mathrm{w}$ zakresie przyjmowanych wartości w obszarze prawa prywatnego międzynarodowego nie są jednolite. Ograniczone posługiwanie się klauzulą korekcyjną przez prawodawcę krajowego wpływa na zwiększenie przewidywalności wskazania prawa właściwego. Równocześnie uczynienie jej jednym z podstawowych mechanizmów kolizyjnoprawnych w aktach prawa unijnego prowadzi do zdecydowanie większej elastyczności stosowania norm kolizyjnych ${ }^{51}$. Sprzyja również indywidualnym rozstrzygnięciom w zakresie wskazania prawa właściwego, przez pozostawienie większej swobody organom stosującym prawo na etapie wyznaczenia prawa właściwego ${ }^{52}$.

Poszczególne centra decyzyjne w ramach multicentrycznego systemu źródeł prawa prywatnego międzynarodowego niezależnie od siebie mogą preferować w różnym stopniu określone wartości, które mają urzeczywistniać normy kolizyjne. W konsekwencji stworzenie jednolitego katalogu uniwersalnych wartości preferowanych przez centra decyzyjne w zakresie prawa prywatnego międzynarodowego może być możliwe z zastrzeżeniem, że stopień realizacji poszczególnych wartości będzie kształtował się na różnym poziomie.

49 Por. K. Roosevelt, op. cit., s. 25.

50 Zob. P. Twardoch, [w:] Prawo prywatne międzynarodowe. Komentarz, red. M. Pazdan, s. 463.

51 Zob. S.C. Symeonides, The American Choice-of-Law Revolution in the Courts: Today and the Tomorrow, Lejda-Boston 2002, s. 66.

52 Por. K. Roosevelt, op. cit., s. 25. 


\title{
PODSUMOWANIE
}

Normy kolizyjne prawa prywatnego międzynarodowego są nośnikiem wartości, a racjonalny prawodawca na etapie ich tworzenia dokonuje wyboru, które z nich powinny zostać urzeczywistnione za pomocą norm kolizyjnych. W zależności od preferencji racjonalnego prawodawcy poszczególne wartości są urzeczywistniane w mniejszym lub większym stopniu. Należy przy tym podkreślić, że niektóre wartości realizowane przez normy kolizyjne, jak na przykład pewność wskazania prawa właściwego i elastyczność ustalenia prawa właściwego, mają przeciwstawny charakter, w konsekwencji realizacja jednej ze wskazanych wartości w większym stopniu będzie automatycznie powodować ograniczenie realizacji przeciwstawnej do niej wartości. Prowadzone rozważania skłaniają do konkluzji, że nie sposób ustalić jednolitego schematu rozstrzygającego, które wartości są szczególnie preferowane $\mathrm{w}$ prawie prywatnym międzynarodowym przez racjonalnego prawodawcę. Należy bowiem pamiętać, że system źródeł prawa prywatnego międzynarodowego jest układem multuicentrycznym, na którego kształt mają wpływ różne ośrodki decyzyjne, a w konsekwencji schemat preferencji poszczególnych wartości kształtuje się odmiennie w każdym z centrów decyzyjnych.

\section{VALUES PREFERRED BY RATIONAL LEGISLATOR IN PRIVATE INTERNATIONAL LAW}

\author{
Summary
}

Conflict of laws rules of private international law are characterised by a different structure than rules of substantive law, which is conditioned by the purpose they serve. The doctrine indicates that conflict of laws rules have purely a technical nature, therefore the question arises are whether these rules a carrier of values, the same as substantive law rules. Assuming however that conflict of laws rules are a carrier of values requires further inquiry concerning values which these norms serve, and which values should be particularly favoured by a rational legislator. The purpose of this study is an indication what values are implemented by conflict of laws rules adopted by a rational legislator.

Keywords: general part of private international law, values in private international law, parties will autonomy in private international law, closest connection in private international law, determination of law applicable

\section{BIBLIOGRAFIA}

Belohlávek A.J., Rome Convention - Rome I Regulation. Commentary, Juris 2010.

Bogdan M., Private International Law as Component of the Law of the Forum, Haga 2012.

Boroń J., Dąbroś M., Dziadek Z., Metoda analizy funkcjonalnej — równoprawna metoda kolizyjna?, Problemy prawa prywatnego międzynarodowego, t. 15, red. M. Pazdan, Katowice 2014. 
Brilmayer L., The role of substantive and choice of law policies in the formation and application of choice of law rules (volume 252), [w:] Collected Courses of the Hague Academy of International Law, Dordrecht-Boston-London 1995.

Czepelak M., Międzynarodowe prawo zobowiazań Unii Europejskiej, Warszawa 2012.

De Boer T., Facultative choice of law: The procedural status of choice-of-law rules and foreign law, [w:] Le Recueil des cours, t. 257 (1996), Haga 1997.

De Boer T., Teaching private international law and comprative law, [w:] Contemporary International Law Issues: Opportunities at a Time of Momentous Change: Proceedings of the Second Joint Conference Held in The Hague, The Netherlands, July 22-24, 1993, Dordrecht-Boston-London 1994.

Gołaczyński J., Prawo prywatne międzynarodowe, Warszawa 2011.

Kalenský P., Trends of Private International Law, Haga 1971.

Kalisz A., Multicentryczność systemu prawa polskiego a działalność orzecznicza Europejskiego Trybunału Sprawiedliwości i Europejskiego Trybunału Praw Człowieka, „Ruch Prawniczy, Ekonomiczny i Socjologiczny" 2007, z. 4.

Kegel G., The crisis of conflicts of laws (volume 112), [w:] Collected Courses of the Hague Academy of International Law, Sijthoff 1964.

Krotoszyński M., Legislative history, ratio legis, and the concept of rational legislator, [w:] Ratio Legis. Philosophical and Theoretical Perspectives, red. V. Klappstein, M. Dybowski, Heidelberg 2018.

Lipstein K., Principles of The Conflict of Laws, National and International, Haga 1981.

Łętowska E., Multicentryczność współczesnego systemu prawa i jej konsekwencje, „Państwo i Prawo" $2005, \mathrm{nr} 4$.

Machnikowski P., Swoboda umów wedlug art. $353^{1}$ KC. Konstrukcja prawna, Warszawa 2005.

Michaels R., Private international law and the question of universal values, [w:] Private International Law Contemporary Challenges and Continuing Relevance, red. F. Ferrari, D.P.F. Arroyo, Cheltenham 2019.

Michaels R., Private international law as an ethic of responsivity (September 14, 2018). Forthcoming, diversity and integration in private international law (Veronica Ruiz Abou-Nigm \& Maria Blanca Noodt Taquela eds., Edinburgh University Press, 2019), „Duke Law School Public Law \& Legal Theory Series" 2018, nr 57, https://ssrn.com/abstract=3251422.

Mostowik P., O uzasadnionych powodach nieprzystapienia Polski do rozporzadzeń UE nr 2016/1103 i 2016/1104 dotyczacych wewnętrznych $i$ zewnętrznych relacji matżonków i rejestrowanych partnerów, [w:] Kolizyjne i procesowe aspekty prawa rodzinnego, red. J. Gołaczyński, W. Popiołek, Warszawa 2019.

Pajor T., Nowe tendencje w części ogólnej prawa prywatnego międzynarodowego państw europejskich, PPHZ 1995, nr 18.

Pazdan M., [w:] System Prawa Prywatnego, t. 20A. Prawo prywatne międzynarodowe, red. M. Pazdan, Warszawa 2014.

Pazdan M., Koordynacja krajowego i europejskiego prawa prywatnego międzynarodowego, [w:] Wspótczesne wyzwania prawa prywatnego międzynarodowego, red. J. Poczobut, Warszawa 2013.

Pilich M., Zasada obywatelstwa w prawie prywatnym międzynarodowym. Zagadnienia podstawowe, Warszawa 2015.

Poczobut J., [w:] Prawo prywatne międzynarodowe. Komentarz, red. J. Poczobut, Warszawa 2017.

Ragno F., Certainity versus flexibility in the EU choice of law system, [w:] Private International Law Contemporary Challenges and Continuing Relevance, red. F. Ferrari, D.P.F. Arroyo, Cheltenham 2019.

Przegląd Prawa i Administracji CXX, 2020, cz. 1 i 2

(C) for this edition by CNS 
Remien O., Germany: Proof of and information about foreign law - duty to investigate, expert opinions and a proposal for Europe, [w:] Treatment of Foreign Law - Dynamics towards Convergence?, red. Y. Nishitani, Heidelberg 2017.

Rodziewicz P., Stwierdzenie treści oraz zastosowanie prawa obcego w sądowym postępowaniu cywilnym, Warszawa 2015.

Roosevelt K., Certainty vs. flexibility in the conflict of laws, [w:] Private International Law: Contemporary Challenges and Continuing Relevance, red. F. Ferrari, D. Fernández Arroyo, Elgar 2019, „U of Penn Law School, Public Law Research Paper”, nr 18-40, https://ssrn.com/abstract $=3301554$.

Sachse K., Der Verbrauchervertrag im Internationalen Privat- und Prozessrecht, Tübingen 2006.

Shapira A., Tort choice of law in Israel: Putting order in a methodological chaos, [w:] Private Law in the International Arena: From National Conflict Rules Towards Harmonization and Unification - Liber Amicorum Kurt Siehr, red. J. Basedow, I. Meier, A.K. Schnyder, T. Einhorn, D. Girsberger, Haga 2000.

Symeonides S.C., The American Choice-of-Law Revolution in the Courts: Today and the Tomorrow, Lejda-Boston 2002.

Symeonides S.C., Codyfing Choice of Law Around the World. An International Comparative Analysis, Oxford 2014.

Trammer H., Z rozważań nad struktura normy kolizyjnej prawa prywatnego międzynarodowego, SC 12-14, 1969.

Twardoch P., [w:] Prawo prywatne międzynarodowe. Komentarz, red. M. Pazdan, Warszawa 2018.

Vischer F.B., General course on private international law (volume 232), [w:] Collected Courses of the Hague Academy of International Law, Dordrecht-Boston-London 1992.

Zachariasiewicz M., Prawo prywatne międzynarodowe. Komentarz, red. M. Pazdan, Warszawa 2018. 